\title{
FAKTOR-FAKTOR YANG MEMPENGARUHI PENERAPAN SISTEM AKUNTABILITAS KINERJA INSTANSI PEMERINTAH (SAKIP) PADA PEMERINTAH PROVINSI SULAWESI UTARA
}

\author{
Harsya K. Tahir, Agus T. Poputra, Jessy D. L. Warongan \\ (Email: harsya_tahir@yahoo.com)
}

\begin{abstract}
The purpose of this research is to analysis the factors which affecting the implementation of the SAKIP in Government of North Sulawesi, the contain is factor awareness on the laws and regulation $\left(X_{1}\right)$, factor organizational commitment $\left(X_{2}\right)$ and factor role of APIP $\left(X_{3}\right)$ toward implementation of SAKIP $(Y)$. Method that use in this research are quantitative method. The data analysis technique has been done by using the multiple linear regressions analysis. Result of the research according the partial test show that awareness on the laws and regulation no significantly effect to the implementation of SAKIP, whereas the organizatoinal commitment and role of APIP has significantly effect to the implementation of SAKIP. The value from coefficient of determination test amount of 43,7\% has been effect by awareness on the laws and regulation, organizatoinal commitment, role of APIP, whereas the remaining 56,3\% is influenced by other factors outside this research.

Keywords : awareness of the laws and regulation, commitment of organization, role of APIP, and SAKIP
\end{abstract}

\section{PENDAHULUAN}

Usaha serius untuk melakukan desentralisasi terjadi setelah rezim orde baru tumbang dan berganti dengan orde reformasi. Pada masa itu berlaku hukum desentralisasi baru untuk menggantikan UU No. 5 tahun 1974, yakni dengan memberlakukan UU No. 22 tahun 1999 tentang Pemerintah Daerah dan UU No. 25 tahun 1999 tentang Perimbangan Keuangan Antara Pemerintah Pusat dan Daerah. UU otonomi daerah kemudian disempurnakan kembali dengan dikeluarkannya UU No. 32 tahun 2004 tentang Pemerintah Daerah dan yang terakhir telah terbit UU No. 9 tahun 2015 tentang Pemerintah Daerah. dan UU No. 25 tahun 1999 tentang Perimbangan Keuangan Antara Pemerintah Pusat dan Daerah diganti dengan UU No. 33 tahun 2004 tentang Perimbangan Keuangan Antara Pemerintah Pusat dan Pemerintah Daerah.

Salah satu hubungan kekuasaan yang berubah melalui kedua UU tersebut adalah desentralisasi, yang berarti penyerahan kewenangan dari pemerintah pusat ke pemerintah daerah. Yuwono, et al (2008:13) menyatakan, perbedaan terpenting antara konsep desentralisasi dan sentralisasi dalam penerapannya di lembaga sektor publik adalah adanya pembagian kewenangan secara mendasar yang diberikan kepada unit pemerintahan yang lebih rendah. Kebijakan desentralisasi pada dasarnya bertujuan untuk membebaskan pemerintah pusat dari beban urusan domestik sehingga pemerintah pusat berkesempatan untuk mempelajari, memahami, dan merespons berbagai kecenderungan global serta lebih mampu berkonsentrasi pada perumusan kebijakan makronasional yang bersifat strategis.

Konsep akuntabilitas menurut Mardiasmo (2009:21) merupakan konsep yang lebih luas dari stewardship. Stewardship mengacu pada pengelolaan atas suatu aktivitas secara ekonomi dan efisien tanpa dibebani kewajiban untuk melaporkan, sedangkan akuntabilitas mengacu pada pertanggungjawaban oleh seorang steward kepada pemberi tanggung jawab. Hal ini berkaitan dengan teori keagenan yang dijabarkan diatas. Menurut Lukito (2014:2), membangun 
akuntabilitas melalui pelaporan kinerja pembangunan secara transparan kepada publik perlu dilakukan oleh pemerintah yang ingin mendapatkan trust atau kepercayaan dari masyarakatnya. Dalam rangka itu diperlukan pengembangan dan penerapan sistem pertanggungjawaban yang tepat, jelas, terukur, dan sah sehingga penyelenggaraan pemerintahan dan pembangunan dapat berlangsung secara berdayaguna, berhasil guna, bersih dan bertanggungjawab serta bebas dari korupsi, kolusi dan nepotisme.

Wujud dari pertanggungjawaban tersebut saat ini adalah dengan dikembangkannya satu sistem pertanggungjawaban yang disebut Sistem Akuntabilitas Kinerja Instansi Pemerintah (SAKIP) yang implementasinya dimulai sejak penyusunan Rencana Strategis (Renstra) sampai dengan pertanggungjawaban kinerja dalam bentuk Laporan Akuntabilitas Kinerja Instansi Pemerintah (LAKIP). SAKIP merupakan salah satu alat manajemen dalam rangka penyelenggaraan pemerintah terdesentralisasi yang diharapkan mampu memperbaiki kinerja pemerintah. Namun dalam barisan daftar laporan yang harus disusun oleh pemerintah daerah, LAKIP sering dianggap sebelah mata baik oleh anggota dewan ataupun penyelenggara pemerintahan itu sendiri. LAKIP tidak begitu populer dibandingkan dengan Laporan Keuangan Pemerintah Daerah (LKPD) dalam hal proses penyusunan dan manfaat yang bisa dirasakan oleh pengguna. Kalau kualitas laporan keuangan dinilai berdasarkan opini yang diberikan Badan Pemeriksa Keuangan (BPK) maka kualitas LAKIP ditentukan oleh penilaian hasil evaluasi yang dilakukan Kemen PAN dan RB.

Berdasarkan sumber dari Biro Organisasi Sekretariat Daerah Provinsi Sulawesi Utara tahun 2016, hasil evaluasi Kemen PAN dan RB atas penerapan SAKIP Provinsi Sulawesi Utara selang tiga tahun terakhir dari tahun 2013-2105 pemerintah melalui Kemen PAN dan RB memberikan predikat "B" sesuai yang diamanatkan Permen PAN dan RB No.12 tahun 2015 tentang Pedoman Evaluasi atas Implementasi Sistem Akuntabilitas Kinerja Instansi Pemerintah. Penerapan SAKIP Provinsi Sulawesi Utara yang diungkapkan dalam LAKIP kemudian dievaluasi oleh Kemen PAN dan RB ternyata belum sepenuhnya memenuhi kriteria untuk mencapai predikat sangat baik apalagi memuaskan karena penilaian pada beberapa instansi atau Satuan Kerja Perangkat Daerah (SKPD) masih terdapat kekurangan berupa ketidak-selarasan antara rencana strategis lima tahunan dan rencana kinerja tahunan yang dituangkan kedalam penganggaran, serta indikator-indikator kinerja yang diciptakan SKPD belum beroriantasi hasil. Hal-hal inilah yang menjadi pertimbangan dalam pemberian predikat.

Bertolak dari uraian diatas peneliti tertarik untuk mengambil beberapa faktor atau variabel yang digunakan dalam penelitian ini untuk di analisis sesuai dengan kondisi pada Pemerintah Provinsi Sulawesi Utara. Faktor pertama adalah kesadaran pada peraturan perundang-undangan, faktor kedua adalah komitmen organisasi, faktor ketiga adalah peran Aparat Pengawas Intern Pemerintah (APIP) daerah dalam hal ini Inspektorat Provinsi Sulawesi Utara.

\section{TINJAUAN PUSTAKA}

\subsection{Landasan Teori}

\subsubsection{Teori Keagenan}

Karakteristik utama hubungan keagenan terletak pada kontrak pelimpahan wewenang dan tanggungjawab dari prinsipal kepada agen. Pelimpahan ini menimbulkan pemisahan antara klaiman residu dengan otoritas pengambilan keputusan. Jensen dan Meckling (1976:4) menyatakan bahwa hubungan keagenan dapat terjadi pada semua entitas yang mengandalkan pada kontrak, baik eksplisit ataupun implisit, sebagai acuan pranata perilaku partisipan. Oleh karena itu, dapat dikatakan bahwa hubungan keagenan terjadi pada setiap entitas. 
Konsep akuntabilitas dalam penelitian ini dapat dijelaskan menggunakan agency theory, dimana dalam pengertian luas akuntabilitas dapat dipahami sebagai kewajiban pihak pemegang amanah dalam hal ini pemerintah (agent) untuk memberikan pertanggungjawaban, menyajikan, melaporkan, dan mengungkapkan segala aktivitas dan kegiatan yang menjadi tanggung jawabnya kepada pihak pemberi amanah dalam hal ini masyarakat yang diwakili oleh DPRD (principal) yang memiliki hak dan kewenangan untuk meminta pertanggungjawaban.

\subsubsection{Teori Birokrasi}

Birokrasi berhubungan dengan organisasi masyarakat yang disusun secara ideal. Birokrasi dicapai melalui formalisasi aturan, struktur, dan proses di dalam organisasi. Menurut Weber (1948), organisasi birokrasi yang ideal menyertakan delapan karakteristik struktural. Muskamal (2014) menyatakan untuk dapat meluruskan kembali birokrasi pada posisi dan misi atau perannya yang sebenamya selaku "pelayan publik" (public servant), diperlukan kemampuan dan kemauan kalangan birokrasi untuk melakukan langkah-langkah reformasi birokrasi yang mencakup perubahan perilaku yang mengedepankan "netralitas, professionalitas, demokratis, transparan, dan mandiri", disertai perbaikan semangat kerja, cara kerja, dan kinerja terutama dalam pengelolaan kebijakan dan pemberian pelayanan publik, serta komitmen dan pemberdayaan akuntabilitas instansi pemerintah. Untuk memperbaiki cara kerja birokrasi diperlukan birokrasi yang berorientasi pada hasil.

Selanjutnya, diperlukan sosok pemimpin yang memiliki komitmen dan kompetensi terhadap reformasi birokrasi negara secara tepat, termasuk dalam penyusunan agenda dan pelaksanaan kebijakan pemerintahan dan pembangunan yang ditujukan pada kepentingan rakyat, peningkatan ketahanan dan daya saing bangsa. Dalam rangka itu, diperlukan pula reformasi struktural, seperti independensi sistem peradilan dan sistem keuangan negara, disertai upaya peningkatan transparansi dan akuntabilitasnya kepada publik.

\subsubsection{Teori Akuntabilitas}

Menurut Turner dan Hulme (1997), akuntabilitas merupakan konsep yang kompleks yang lebih sulit mewujudkannya dari pada memberantas korupsi. Akuntabilitas adalah keharusan lembaga-lembaga sektor publik untuk lebih menekan pada pertanggungjawaban horizontal (masyarakat) bukan hanya pertanggungjawaban vertikal (otoritas yang lebih tinggi). Akuntabilitas adalah pertanggungjawaban dari seseorang atau sekelompok orang yang diberi amanat untuk menjalankan tugas tertentu kepada pihak pemberi amanat baik secara vertikal maupun secara horizontal.

Mardiasmo (2009:20) mengartikan akuntabilitas publik adalah kewajiban pihak pemegang amanah (agent) untuk memberikan pertanggungjawaban, menyajikan, melaporkan dan mengungkapkan segala aktivitas dan kegiatan yang menjadi tanggungjawabnya kepada pemberi amanah (principal) yang memiliki hak dan kewenangan untuk meminta pertanggungjawaban tersebut.

Lukito (2014:2) memaparkan akuntabilitas adalah bentuk kewajiban penyelenggara kegiatan publik untuk dapat menjelaskan dan menjawab segala hal menyangkut langkah dari seluruh keputusan dan proses yang dilakukan, serta pertanggungjawaban terhadap hasil dan kinerjanya. Menurut Setiyono (2014:181) akuntabilitas adalah konsep yang memiliki beberapa makna. Terminologi ini sering digunakan dengan beberapa konsep seperti Answerability, responsibility, liability dan terminologi lain yang berkaitan dengan "the expectation of accountgiving" (harapan pemberi mandat dengan pelaksana mandat). Dengan demikian, accountability mencakup harapan atau asumsi perilaku hubungan antara pemberi dan penerima mandat. 


\subsubsection{Kesadaran pada Peraturan Perundang-Undangan}

Setiap manusia yang normal mempunyai kesadaran pada hukum atau aturan yang berlaku. Berkaitan dengan hal tersebut pendapat Soekanto (1982:140) mengemukakan empat indikator kesadaran hukum yaitu, (1) pengetahuan tentang peraturan-peraturan hukum yang berlaku, baik di lingkungan masyarakat ataupun di negara Indonesia; (2) pemahaman tentang isi peraturanperaturan hukum, contohnya bukan hanya sekedar dia tahu ada hukum tentang pajak, tetapi dia juga mengetahui isi peraturan tentang pajak tersebut; (3) sikap positif terhadap peraturanperaturan hukum; dan (4) menunjukkan perilaku yang sesuai dengan apa yang diharuskan oleh peraturan perundang-undangan yang berlaku. Menurut Salman dan Susanto (2004:153) apabila ke empat indikator kesadaran hukum tersebut betul-betul terlaksana dalam masyarakat sesuai dengan harapan pemerintah serta tidak ada implikasinya, maka peraturan tersebut dapat dianggap efektif.

Efektifitas peraturan dalam suatu sistem organisasi juga tidak terlepas dari faktor ketaatan atau kepatuhan dari tiap anggota organisasi terhadap aturan yang ada. Dalam pendapatnya Kelman (1958:53) membedakan kualitas ketaatan atau kepatuhan terhadap aturan dalam tiga jenis, yaitu (1) Ketaatan yang bersifat compliance, yaitu jika seseorang taat terhadap suatu aturan hanya karena ia takut terkena sanksi; (2) Ketaatan yang bersifat identification, yaitu jika seseorang taat terhadap suatu aturan hanya karena takut hubungan baiknya dengan seseorang menjadi rusak; dan (3) Ketaatan yang bersifat internalization, yaitu jika seseorang taat terhadap suatu aturan karena benar-benar ia merasa bahwa aturan tersebut materi dan spiritnya sesuai dengan nilai-nilai intrinsik yang dianutnya.

\subsubsection{Komitmen Organisasi}

Komitmen organisasi secara umum dapat didefinisikan sebagai keterikatan antara pegawai dan organisasi secara psikologis. Menurut Meyer, Allen, dan Smith (1993) ada 3 sumber komitmen organisasi sebagai berikut, (1) Komitmen afektif (affective commitment) berkaitan dengan keterikatan emosional dan keterlibatan pegawai pada organisasi. Pegawai dengan komitmen afektif yang tinggi akan selalu menjadi anggota dalam organisasi tersebut karena memang memiliki keinginan untuk itu. Hal ini berarti bahwa individu tersebut akan memiliki motivasi dan keinginan untuk berkontribusi secara maksimal terhadap organisasi. Pada dimensi komitmen afektif ini, anggota organisasi memilih organisasi lebih disebabkan adanya dedikasi yang tinggi agar organisasi menjadi lebih berkembang; (2) Komitmen kontinuan (continuance commitment), menunjukan adanya pertimbangan untung rugi dalam diri pegawai yang berkaitan dengan keinginan untuk tetap bekerja atau keluar dari organisasi. Komitmen kontinuan menunjukkan bahwa komitmen anggota organisasi lebih disebabkan biaya hidup. Pegawai dengan komitmen kontinuan yang tinggi bertahan dalam organisasi karena adanya kesadaran kerugian besar yang akan dialami jika meninggalkan organisasi. Pegawai akan menghindari kerugian financial dan kerugian lain, sehingga memungkinkannya melakukan usaha yang tidak maksimal; (3) Komitmen normatif (normative commitment), berkaitan dengan perasaan wajib untuk tetap bekerja dalam organisasi yang didasari pada adanya keyakinan tentang apa yang benar serta berkaitan dengan masalah moral. Komitmen normatif menimbulkan perasaan kewajiban pada pegawai untuk memberi balasan atas apa yang telah diterimanya dari organisasi. Pegawai dengan komitmen normatif yang tinggi akan tetap bertahan dalam organisasi karena merasa itu adalah kewajibannya dan harus dilakukan sebagai balasan atas keuntungan yang telah dia terima dari organisasi.

Komitmen pemerintah untuk mewujudkan pemerintah yang transparan dan akuntabel serta bebas Korupsi, Kolusi, dan Nepotisme pada berbagai aspek pelaksanaan tugas umum 
pemerintahan dan pembangunan dituangkan dalam UU No. 28 tahun 1999 tentang Penyelenggaraan Negara yang Bersih dan Bebas dari KKN. Komitmen ini sudah menjadi agenda yang harus dilaksanakan guna tercapainya transparansi dan akuntabilitas publik, tidak terkecuali komitmen APIP untuk selalu meningkatkan peran sertanya dalam mewujudkan pemerintahan yang baik.

\subsubsection{Peran Aparat Pengawas Intern Pemerintah (APIP)}

Menurut Asosiasi Auditor Intern Pemerintah Indonesia (2013:1), APIP sebagai pengawas intern pemerintah merupakan salah satu unsur manajemen pemerintah yang penting dalam rangka mewujudkan kepemerintahan yang baik (good governance) yang mengarah pada pemerintahan/birokrasi yang bersih (clean government). Untuk mencapai tujuan tersebut diperlukan peran APIP yang efektif, yaitu dalam wujud, (1) memberikan keyakinan yang memadai atas ketaatan, kehematan, efisiensi, dan efektivitas pencapaian tujuan penyelenggaraan tugas dan fungsi Instansi Pemerintah (assurance activities); (2) memberikan peringatan dini dan meningkatkan efektivitas manajemen risiko dalam penyelenggaraan tugas dan fungsi Instansi Pemerintah (anti corruption activities); dan (3) memberikan masukan yang dapat memelihara dan meningkatkan kualitas tata kelola penyelenggaraan tugas dan fungsi Instansi Pemerintah (consulting activities).

\subsubsection{Sistem Akuntabilitas Kinerja Instansi Pemerintah (SAKIP)}

Sistem adalah kesatuan unsur atau unit yang saling berhubungan dan saling mempengaruhi sedemikian rupa, sehingga muncul dalam bentuk keseluruhan, bekerja, berfungsi atau bergerak secara harmonis yang ditopang oleh sejumlah prosedur yang diperlukan, sedangkan prosedur merupakan urutan kinerja atau kegiatan yang terencana untuk menangani pekerjaan yang berulang dengan cara seragam dan terpadu. (menerangkan sumber informasi)

Menurut LAN (2003:3) SAKIP pada pokoknya adalah instrumen yang digunakan instansi pemerintah dalam memenuhi kewajiban untuk memperpertanggungjawabkan keberhasilan maupun kegagalan pelaksanaan misi organisasi, terdiri dari berbagai komponen yang merupakan satu kesatuan, yaitu perencanaan strategis, perencanaan kinerja, pengukuran kinerja, dan pelaporan kinerja.

\section{HIPOTESIS}

\subsection{Hipotesis Penelitian}

\subsubsection{Pengaruh Kesadaran pada Peraturan Perundang-undangan terhadap Penerapan SAKIP}

Penelitian Riantiarno dan Azlina (2011) mengungkapkan kepatuhan atau ketaatan pada peraturan perundangan berpengaruh terhadap akuntabilitas kinerja instansi pemerintah. Kondisi ini memperlihatkan bahwa keberhasilan penerapan akuntabilitas kinerja instansi pemerintah pada daerah yang mereka teliti yaitu Kabupaten Rokan Hulu ditentukan langsung oleh ketaatan pada peraturan perundang-undangan.

Hal serupa juga diungkapkan oleh Soleman (2007), dimana ketaatan pada peraturan perundang-undangan berpengaruh sangat signifikan terhadap akuntabilitas kinerja instansi pemerintah. Berbeda dengan penelitian yang dilakukan oleh Nasriani dan Chandra (2009), hasil pengujian secara parsial menunjukkan bahwa variabel kesadaran tentang akuntabilitas serta variabel hukum tentang akuntabilitas tidak mempunyai pengaruh yang signifikan terhadap implementasi SAKIP. Berdasarkan hal tersebut hipotesis yang diangkat adalah sebagai berikut.

$\mathrm{Ha}_{1}$ : Kesadaran Pada Peraturan Perundang-Undangan berpengaruh signifikan terhadap Penerapan SAKIP. 


\subsubsection{Pengaruh Komitmen Organisasi terhadap Penerapan SAKIP}

Penelitian yang dilakukan oleh Silvia (2013) menunjukkan komitmen manajemen berpengaruh signifikan positif terhadap akuntabilitas kinerja instansi pemerintah. Artinya semakin tinggi komitmen manajemen, maka akan semakin baik pula akuntabilitas kinerja yang dihasilkan oleh instansi pemerintah.

Penelitian ini sejalan dengan penelitian yang dilakukan Nurkhamid (2008), Norman (2010) tentang komitmen manajemen terhadap akuntabilitas kinerja instansi pemerintah menunjukkan hasil yang positif dan signifikan. Mereka menemukan bahwa keberadaan komitmen manajemen yang tinggi akan meningkatkan akuntabilitas kinerja. Komitmen manajemen yang tinggi menjadikan individu peduli dengan nasib organisasi dan berusaha menjadikan organisasi kearah yang lebih baik, berdasarkan hal tersebut hipotesis yang diangkat adalah sebagai berikut.

$\mathrm{Ha}_{2}$ : Komitmen Organisasi berpengaruh signifikan terhadap Penerapan SAKIP.

\subsubsection{Pengaruh Peran APIP terhadap Penerapan SAKIP}

Penelitian yang dilakukan Astuti (2013), menunjukkan bahwa ada pengaruh fungsi pemeriksaan intern terhadap kinerja pemerintah daerah di DPPKAD Kabupaten Grobogan. Dengan demikian dapat disimpulkan bahwa fungsi pemeriksaan intern yang baik dapat meningkatkan kinerja pemerintah daerah, berdasarkan hal tersebut hipotesis yang diangkat adalah sebagai berikut.

$\mathrm{Ha}_{3}$ : Peran APIP berpengaruh signifikan terhadap Penerapan SAKIP.

\subsection{Kerangka Konseptual}

Kerangka konseptual yang dibangun dalam penelitian ini diharapkan dapat menggambarkan tentang penelitian yang akan dilakukan penulis secara keseluruhan, yaitu menganalisis faktor Kesadaran pada peraturan perundang-undangan, Komitmen Organisasi, serta Peran APIP terhadap penerapan SAKIP pada Pemerintah Provinsi Sulawesi Utara. Kerangka konsep dalam penelitian ini mengambarkan paradigma metode penelitian secara komprehensif, yang dapat digambarkan dalam suatu skema kerangka proses berpikir seperti pada Gambar 3.1.

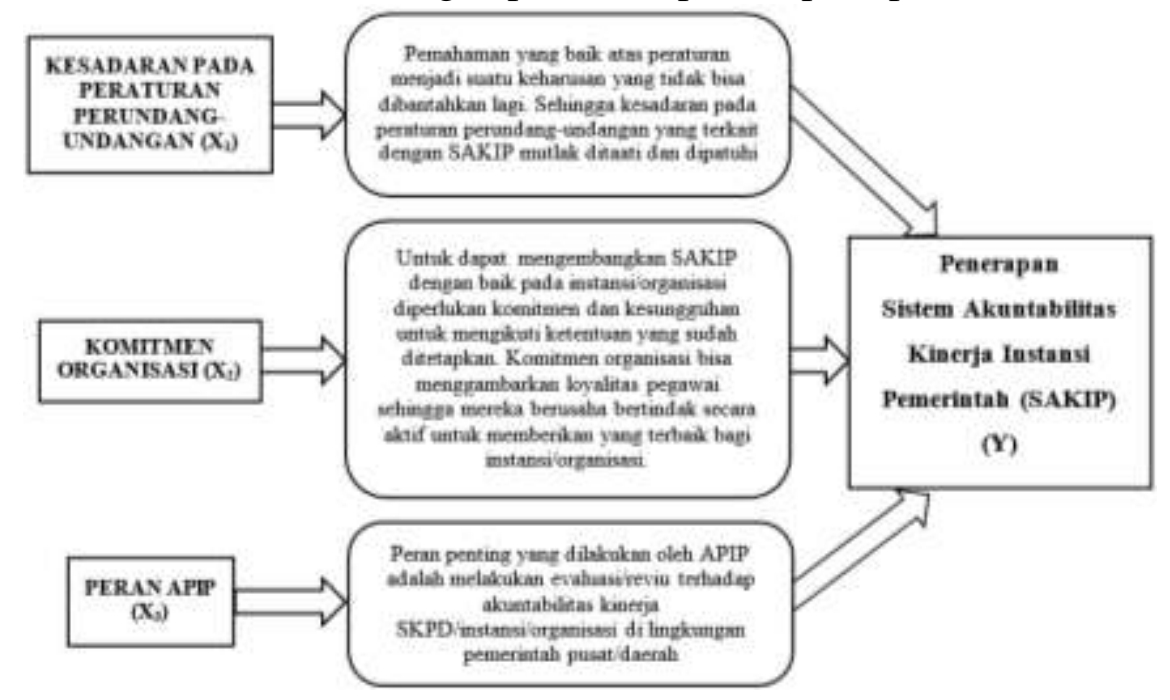

Gambar 3.1 Kerangka Konseptual

\subsection{Model Analisis}

Analisis yang digunakan dalam penelitian ini adalah analisis regresi linier berganda. Menurut Ghozali (2006), analisis regresi linier berganda digunakan untuk mengukur pengaruh 
antara lebih dari satu variabel predictor (variabel bebas) terhadap variabel terikat. Model analisis dalam penelitian ini adalah sebagai berikut:

$$
Y=\alpha+\beta_{1} X_{1}+\beta_{2} X_{2}+\beta_{3} X_{3}+€
$$

\section{METODE PENELITIAN}

\subsection{Data}

\subsubsection{Jenis Penelitian}

Jenis penelitian ini menggunakan penelitian pendekatan kuantitatif untuk menganalisis "Faktor-faktor yang mempengaruhi Penerapan Sistem Akuntabilitas Kinerja Instansi Pemerintah pada Pemerintah Provinsi Sulawesi Utara". Berdasarkan hubungan antara variabel yang diteliti, maka penelitian ini merupakan penelitian asosiatif kausal yaitu hubungan yang bersifat sebabakibat.

\subsection{Populasi, Teknik Pengambilan Sampel dan Besar Sampel}

Populasi dalam penelitian ini adalah Aparatur Sipil Negara (ASN) pada Pemerintah Provinsi Sulawesi Utara yang bekerja dibidang perencanaan, pelaporan, dan atau bidang lain terdiri dari staf pelaksana, pejabat eselon IV sub bagian perencanaan, pelaporan, dan atau sub bagian lain yang bertugas menyiapkan laporan kinerja SKPD dan pejabat eselon III yang kompeten dalam memberikan informasi dan pendapat mengenai SAKIP serta APIP yang melaksanakan fungsi pengawasan atas laporan kinerja SKPD. Jumlah populasi sebesar 124 ASN tersebar di 20 SKPD pada Pemerintah Provinsi Sulawesi Utara.

Teknik pengambilan sampel dalam penelitian ini menggunakan Nonprobability Sampling dengan teknik sampling purposive adalah teknik penentuan sampel berdasarkan pertimbangan tertentu dalam hal ini akan melakukan penelitian tentang Sistem Akuntabilitas Kinerja Instansi Pemerintah maka respondennya adalah orang-orang yang kompeten saat ini dalam pelaporan akuntabilitas kinerja serta orang yang melakukan evaluasi terhadap pelaporan kinerja tersebut dalam hal ini APIP.

Sementara sampel dalam penelitian ini yaitu ASN yang bekerja dibidang perencanaan, pelaporan, dan atau bidang lain yang terdiri dari staf pelaksana, pejabat eselon IV atau kepala pada sub bagian perencanaan, pelaporan, dan atau kepala sub bagian lain yang bertugas menyiapkan laporan kinerja SKPD dan pejabat eselon III yang kompeten dalam memberikan informasi dan pendapat mengenai SAKIP serta APIP yang melaksanakan fungsi pengawasan dan yang kompeten melakukan evaluasi atas laporan kinerja SKPD. Sampel dalam penelitian ini berjumlah 100 responden/ASN dan tersebar di 20 SKPD pada Pemerintah Provinsi Sulawesi Utara.

\subsection{Lokasi dan Waktu Penelitian}

Penelitian ini dilakukan terhadap ASN yang bekerja pada 20 SKPD Pemerintah Provinsi Sulawesi Utara. Dengan jangka waktu penelitian selama 3 bulan yaitu mulai bulan Juni sampai dengan bulan Agustus 2016.

\subsection{Definisi Operasional dan Pengukuran Variabel}

\subsubsection{Kesadaran Pada Peraturan perundang-Undangan $\left(X_{1}\right)$}

Tabel 4.1 Operasionalisasi Variabel dan Pengukuran Variabel Kesadaran Pada Peraturan Perundang-Undangan 


\begin{tabular}{|c|c|c|c|}
\hline Variabel & Indikator & $\begin{array}{c}\text { No. Item } \\
\text { Pernyataan }\end{array}$ & Data \\
\hline \multirow{4}{*}{$\begin{array}{l}\text { Kesadaran Pada } \\
\text { Peraturan Perundang- } \\
\text { undangan }\left(\mathrm{X}_{1}\right)\end{array}$} & $\begin{array}{l}\text { I. Memiliki Pengetahuan Tentang Peraturan Hukum } \\
\text { yang Berlaku }\end{array}$ & $1 \& 2$ & Interva \\
\hline & II. Memahami Isi Peraturan & $3,4 \& 5$ & Interva \\
\hline & III. Memiliki Sifat Positif terhadap peraturan & $6 \& 7$ & Interva \\
\hline & $\begin{array}{l}\text { IV. Menunjukkan perilaku yang sesuai dengan apa } \\
\text { yang diharuskan oleh peraturna perundang- } \\
\text { undangan yang berlaku }\end{array}$ & 8 & Interva \\
\hline
\end{tabular}

Sumber: Soerjono Soekanto. (1982:140) Kesadaran Hukum dan Kepatuhan Hukum Jakarta: Rajawali Press

\subsubsection{Komitmen Organisasi $\left(\mathrm{X}_{2}\right)$}

Tabel 4.2 Operasionalisasi Variabel dan Pengukuran Variabel Komitmen Organisasi

\begin{tabular}{|c|c|c|c|}
\hline $\begin{array}{c}\text { Variabel } \\
\text { Komitmen Organisasi }\left(\mathrm{X}_{2}\right)\end{array}$ & Indikator & No. Item Pernyataan & Data \\
\hline \multirow{3}{*}{ Komitmen Organisasi $\left(\mathrm{X}_{2}\right)$} & I. Affective Commitment & $1,2 \& 3$ & Interval \\
\hline & II. Continuance Commitment & $4,5 \& 6$ & Interval \\
\hline & III. Normative Commitment & $7 \& 8$ & Interval \\
\hline
\end{tabular}

Sumber: Meyer and Allen (1997) "Commitment in the workplace theory research and aplication". California: Sage Publication.

\subsubsection{Peran APIP $\left(\mathrm{X}_{3}\right)$}

Tabel 4.3 Operasionalisasi Variabel dan Pengukuran Variabel Peran APIP

\begin{tabular}{|c|c|c|c|}
\hline Variabel & Indikator & No. Item Pernyataan & Data \\
\hline \multirow[t]{3}{*}{ Peran APIP $\left(X_{3}\right)$} & $\begin{array}{l}\text { I. Memberikan Keyakinan } \\
\text { (Assurance Activity) }\end{array}$ & $1,2 \& 3$ & Interval \\
\hline & $\begin{array}{l}\text { II. Memberikan Peringatan Dini } \\
\text { (Anti Corruption Activity) }\end{array}$ & $4,5 \& 6$ & Interval \\
\hline & $\begin{array}{l}\text { III. Memelihara dan meningkatkan Kualitas Tata } \\
\text { Kelola (Consulting Activity) }\end{array}$ & $7 \& 8$ & Interval \\
\hline
\end{tabular}

Sumber: Peraturan Pemerintah No. 60 Tahun 2008 tentang Sistem Pengendalian Intern Pemerintah, Pasal 11 mengenai perwujudan peran aparat pengawasan intern pemerintah yang efektif.

4.4.4 Penerapan Sistem Akuntabilitas Kinerja Instansi Pemerintah (SAKIP) (Y)

Tabel 4.6 Operasionalisasi Variabel dan Pengukuran Variabel Penerapan SAKIP

\begin{tabular}{|c|c|c|c|}
\hline Variabel & Indikator & No. Item Pernyataan & Data \\
\hline \multirow{6}{*}{ Penerapan SAKIP (Y) } & I. Rencana Strategis & $1,2,3,4 \& 5$ & Interval \\
\hline & II. Perjanjian Kinerja & $6,7,8 \& 9$ & Interval \\
\hline & III. Pengukuran Kinerja & $10 \& 11$ & Interval \\
\hline & IV. Pengelolaan Data Kinerja & $12,13 \& 14$ & Interval \\
\hline & V. Pelaporan Kinerja & $15,16 \& 17$ & Interval \\
\hline & VI. Reviu dan Evaluasi Kinerja & $18,19 \& 20$ & Interval \\
\hline
\end{tabular}

Sumber: Perpres No. 29 tahun 2014 tentang Sistem Akuntabilitas Kinerja Instansi Pemerintah, Pasal 5.

\subsection{Analisis Deskriptif}

Analisis deskriptif dalam penelitian ini adalah upaya menyelidiki secara mendalam tentang data yang berhasil diperoleh peneliti selama penelitian berlangsung, sehingga akan diketahui makna dan keadaan yang sebenarnya dari apa yang telah diteliti. Analisis deskriptif dalam penelitian ini meliputi: (1) Tabulasi Data; (2) Deskriptif responden; (3) Statistik deskriptif. 


\subsection{Uji Asumsi Klasik}

Sebelum data dianalisis lebih lanjut menggunakan analisis regresi berganda, terlebih dahulu dilakukan uji asumsi klasik yang terdiri dari Uji Normalitas, Uji Multikolinieritas dan Uji Heterokedastisitas.

\subsection{Uji Hipotesis}

Penelitian ini menggunakan 3 variabel independen dan satu variabel dependen. Metode analisis yang digunakan untuk menguji hipotesis adalah metode regresi berganda (multiple regression), yaitu regresi yang digunakan untuk menguji $\mathrm{Ha}_{1}, \mathrm{Ha}_{2}$ dan $\mathrm{Ha}_{3}$ dengan pendekatan interaksi yang bertujuan untuk memenuhi ekspektasi penelitian mengenai "Faktor-Faktor Yang Mempengaruhi Penerapan Sistem Akuntabilitas Kinerja Instansi Pemerintah (SAKIP) Pada Pemerintah Provinsi Sulawesi Utara". Sementara itu, langkah-langkah untuk menguji pengaruh variabel independen, yaitu Kesadaran pada Peraturan Perundang-undangan, Komitmen Organisasi, dan Peran APIP dilakukan dengan uji statistik melalui, (1) Uji bersama-sama (Uji F); (2) Uji parsial (Uji t); (3) Uji koefisien korelasi dan koefisien determinasi.

\subsection{Hasil Analisis}

\section{ANALISIS DAN PEMBAHASAN}

\subsubsection{Uji Validitas dan Reliabilitas}

Uji validitas dan reliabilitas yang dilakukan pada variabel kesadaran pada peraturan perundang-undangan $\left(\mathrm{X}_{1}\right)$ semua pernyataan berjumlah 8 item yang diajukan adalah valid serta handal dengan nilai Cronbach's alpha 0,7776. Uji validitas dan reliabilitas yang dilakukan pada variabel komitmen organisasi $\left(\mathrm{X}_{2}\right)$ semua pernyataan berjumlah 8 item yang diajukan adalah valid serta handal dengan nilai Cronbach's alpha 0,855 . Uji validitas dan reliabilitas yang dilakukan pada variabel peran APIP $\left(\mathrm{X}_{3}\right)$ semua pernyataan berjumlah 8 item yang diajukan adalah valid serta handal dengan nilai Cronbach's alpha 0,909. Uji validitas dan reliabilitas yang dilakukan pada variabel penerapan SAKIP (Y) semua pernyataan berjumlah 20 item yang diajukan adalah valid serta handal dengan nilai Cronbach's alpha 0,961.

\subsubsection{Statistik Deskriptif}

Tabel. 5.1 Statistik Deskriptif

\begin{tabular}{llllllll}
\hline Variabel & $N$ & Range & Minimum & Maximum & Mean & Std. Deviation & Variance \\
\hline Kesadaran & 100 & 16 & 24 & 40 & 32.61 & 3.275 & 10.725 \\
\hline Komitmen & 100 & 18 & 22 & 40 & 32.99 & 3.563 & 12.697 \\
\hline APIP & 100 & 16 & 24 & 40 & 32.32 & 3.819 & 14.583 \\
\hline SAKIP & 100 & 28 & 72 & 100 & 85.50 & 7.714 & 59.505 \\
\hline
\end{tabular}

Valid N (listwise) $\quad 100$

Sumber: Hasil olah data dengan SPSS

Berdasarkan hasil uji statistik deskriptif yang dituangkan dalam Tabel 5.1 dapat ditarik kesimpulan bahwa rata-rata jawaban responden terhadap variabel kesadaran pada peraturan perundang-undangan dan variabel peran APIP adalah netral sedangkan variabel komitmen organisasi dan variabel penerapan SAKIP adalah setuju.

\subsubsection{Uji Asumsi Klasik}

\subsubsection{Uji Normalitas}

Uji normalitas dilakukan untuk mengetahui data berdistribusi normal. Pengujian tentang normal tidaknya data dilakukan dengan normal P-Plot. Jika titik-titik data menyebar di sekitar garis diagonal dan penyebaran titik data searah mengikuti garis diagonal, maka model regresi memenuhi asumsi normalitas. Pada gambar 5.1 terlihat bahwa titik data menyebar di sekitar garis 
diagonal dan penyebaran titik-titik data searah mengikuti garis diagonal. Jadi dapat disimpulkan bahwa data terdistribusi dengan normal, sehingga model regresi memenuhi asumsi normalitas.

Tabel 5.2 Hasil Uji Multikoliniearitas

\begin{tabular}{llll}
\hline \multirow{2}{*}{ Model } & \multicolumn{2}{c}{ Collinearity Statistics } \\
\cline { 3 - 4 } \multicolumn{1}{l}{ (Constant) } & \multicolumn{2}{c}{ Tolerance } & VIF \\
\cline { 2 - 4 } & Kesadaran & 0.731 & 1.369 \\
\cline { 2 - 4 } & Komitmen & 0.845 & 1.184 \\
\hline & APIP & 0.817 & 1.224 \\
\hline
\end{tabular}

Sumber: Hasil olah data dengan SPSS

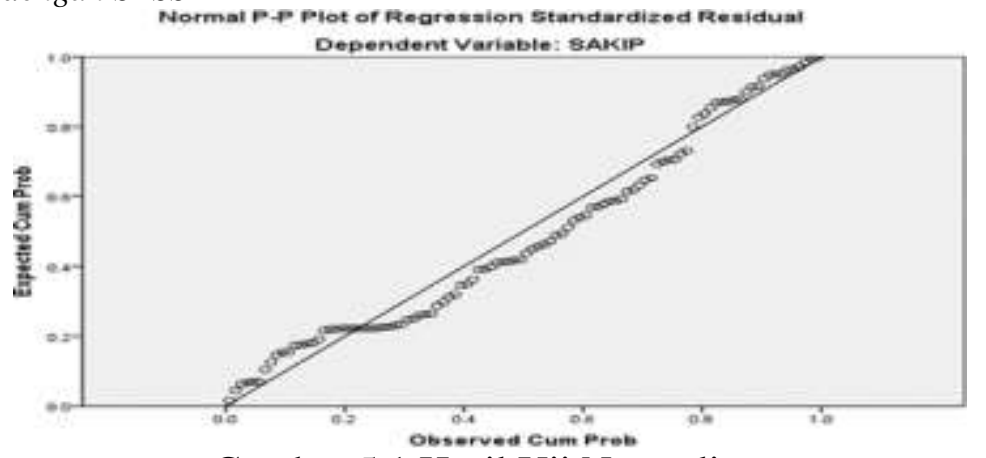

\subsubsection{Uji Multikolinearitas}

Gambar 5.1 Hasil Uji Normalitas

Pengujian multikolinieritas dilakukan untuk melihat apakah pada model regresi ditemukan adanya korelasi antara variabel independen. Cara mendeteksinya adalah dengan melihat nilai tolerance dan nilai Variance Inflation Factor (VIF). Jika nilai VIF $<10$ dan tolerance $>0,1$ maka variabel independen terbebas dari persoalan multikolinieritas. Tabel 5.2 menyajikan hasil uji multikoliniearitas.

Tabel 5.2 menunjukkan bahwa semua nilai tolerance $>0,1$ dan nilai VIF $<10$. Hal ini menunjukkan bahwa semua variabel independen terbebas dari multikolinieritas.

\subsubsection{Uji Heteroskedastisitas}

Ada tidaknya heteroskedastisitas dapat ditentukan dengan melihat grafik plot. Jika tidak ada pola yang jelas, yaitu serat titik-titik menyebar di atas dan di bawah angka 0 pada sumbu $\mathrm{Y}$, maka tidak terjadi heteroskedastisitas.

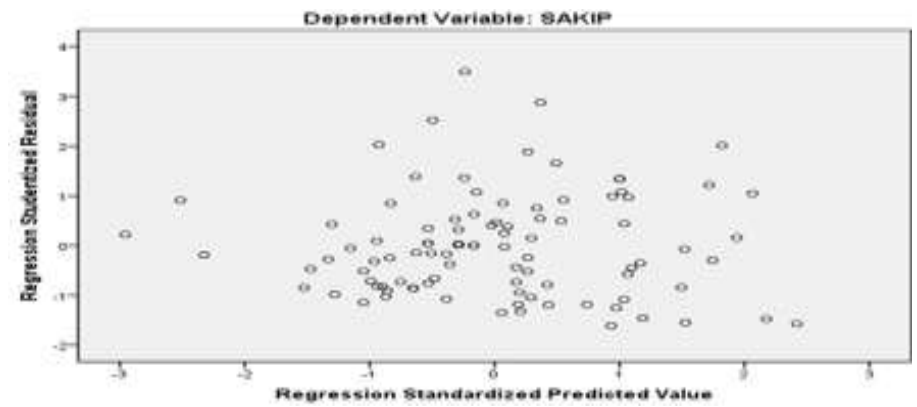

Gambar 5.2 Hasil Uji Heterokedastisitas

Gambar 5.2 memperlihatkan bahwa pada scatterplot, titik-titik yang ada tidak membentuk sebuah pola namun menyebar, sehingga dapat disimpulkan bahwa dalam penelitian tidak terjadi heterokedastisitas.

Uji heteroskedastisitas yang lain dengan uji Glesjer seperti pada Tabel 5.3. Dasar pengambilan keputusan dalam uji heteroskedastisitas, yaitu: 
1. Tidak terjadi heteroskedastisitas, jika nilai t-hitung lebih kecil dari t-tabel dan nilai signifikansi lebih besar dari 0,05

2. Terjadi heteroskedastisitas, jika nilai t-hitung lebih besar dari t-tabel dan nilai signifikansi lebih kecil dari 0,05

Tabel 5.3 Hasil Uji Heteroskedastisitas

\begin{tabular}{llrr}
\hline \multicolumn{2}{c}{ Model } & \multicolumn{2}{c}{ Sig. } \\
\hline 1 & (Constant) & -.833 & .407 \\
\cline { 2 - 5 } & Kesadaran & .733 & .466 \\
\cline { 2 - 4 } & Komitmen & 1.529 & .130 \\
\cline { 2 - 4 } & APIP & -.009 & .993 \\
\hline
\end{tabular}

Sumber: Hasil olah data dengan SPSS

Tabel 5.3 menunjukkan nilai t-tabel dicari pada distribusi nilai t-tabel dengan $\mathrm{N}=100$ dan $\mathrm{t}=0,050$ maka diperoleh nilai $\mathrm{t}$-tabel $=1,98397$. Berdasarkan uji heteroskedastisitas dengan metode Glesjer diperoleh nilai t-hitung lebih kecil t-tabel dan nilai signifikasi lebih besar dari 0,05, sehingga dapat disimpulkan data tidak terjadi masalah heteroskedastisitas.

\subsubsection{Analisis Regresi Linier Berganda}

Tabel 5.4 Hasil Analisis Regresi Linier Berganda

\begin{tabular}{|c|c|c|c|c|c|c|}
\hline \multicolumn{7}{|c|}{ Coefficients $^{a}$} \\
\hline \multirow[t]{2}{*}{ Model } & & \multicolumn{2}{|c|}{ Unstandardized Coefficients } & \multirow{2}{*}{$\frac{\text { Standardized Coefficients }}{\text { Beta }}$} & \multirow[t]{2}{*}{$t$} & \multirow[t]{2}{*}{ Sig. } \\
\hline & & $B$ & Std. Error & & & \\
\hline \multirow[t]{4}{*}{1} & (Constant) & 27.203 & 7.189 & & 3.784 & .000 \\
\hline & Kesadaran & .042 & 208 & .018 & .203 & .839 \\
\hline & Komitmen & .738 & .178 & 341 & 4.156 & .000 \\
\hline & APIP & 1.008 & .169 & .499 & 5.979 & .000 \\
\hline
\end{tabular}

a. Dependent Variable: SAKIP

Sumber: Hasil olah data dengan SPSS

Berdasarkan Tabel 5.4 diperoleh persamaan regresi linier berganda sebagai berikut:

$$
\mathbf{Y}=\mathbf{2 7 . 2 0 3}+\mathbf{0 . 0 4 2 X 1}+\mathbf{0 . 7 3 8 X 2}+\mathbf{1 . 0 0 8 X 3}+\boldsymbol{€}
$$

Dapat dilihat nilai konstanta $(\alpha)$ sebesar 27.203 dan bernilai positif. Hal ini berarti Penerapan SAKIP (Y) mempunyai hubungan positif atau searah dengan Kesadaran Pada Peraturan Perundang-undangan $\left(\mathrm{X}_{1}\right)$, Komitmen Organisasi $\left(\mathrm{X}_{2}\right)$, dan Peran APIP $\left(\mathrm{X}_{3}\right)$.

\subsubsection{Hasil Pengujian Hipotesis}

5.1.5.1 Uji koefisien regresi secara bersama-sama (uji F)

Tabel 5.5 Hasil Uji F

\begin{tabular}{llrrrrr}
\multicolumn{7}{c}{ ANOVA $^{b}$} \\
Model & & Sum of Squares & $d f$ & Mean Square & \multicolumn{1}{c}{ F } & \multicolumn{1}{c}{ Sig. } \\
\hline \multirow{2}{*}{1} & Regression & 2674.942 & 3 & 891.647 & 26.616 & $.000^{\mathrm{a}}$ \\
\cline { 2 - 7 } & Residual & 3216.058 & 96 & 33.501 & & \\
\cline { 2 - 7 } & Total & 5891.000 & 99 & & & \\
\hline
\end{tabular}

a. Predictors: (Constant), Kesadaran, Komitmen, APIP

b. Dependent Variable: SAKIP

Sumber: Hasil olah data dengan SPSS

Pada Tabel 5.5 menunjukkan bahwa $F_{\text {hitung }}=26,616>F_{\text {tabel }}=2,70$ maka Ha diterima dan Ho ditolak. Dilihat dari nilai signifikansi adalah $0,000<0,05$ sehingga Ha diterima dan Ho ditolak. Hasil pengujian ini menunjukkan bahwa kesadaran pada peraturan perundang-undangan, komitmen organisasi, dan peran APIP secara bersama-sama berpengaruh secara signifikan terhadap penerapan SAKIP. 
5.1.5.2 Uji koefisien regresi secara parsial (uji t)

Tabel 5.6 Hasil Pengujian Parsial (Uji t)

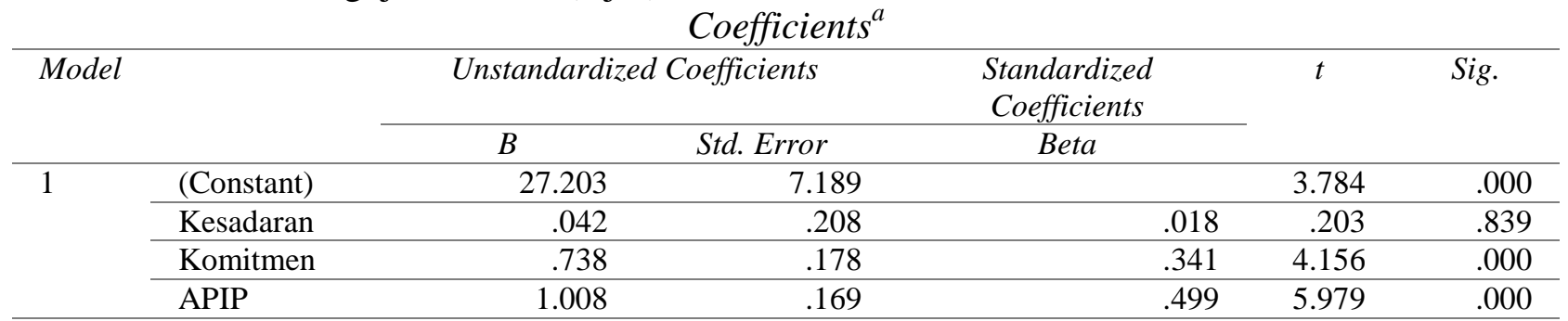

a. Dependent Variable: SAKIP

Sumber: Hasil olah data dengan SPSS

Dari Tabel 5.6 menunjukkan bahwa, (1) $\mathrm{Ha}_{1}$ ditolak dan $\mathrm{Ho}_{1}$ diterima, sehingga tidak terbukti bahwa kesadaran pada peraturan perundang-undangan berpengaruh signifikan terhadap penerapan SAKIP; (2) $\mathrm{Ha}_{2}$ diterima dan $\mathrm{Ho}_{2}$ ditolak, sehingga terbukti bahwa komitmen organisasi berpengaruh signifikan terhadap penerapan SAKIP; (3) $\mathrm{Ha}_{3}$ diterima dan $\mathrm{Ho}_{3}$ ditolak, sehingga terbukti bahwa peran APIP berpengaruh signifikan terhadap penerapan SAKIP.

5.1.5.3 Uji koefisien korelasi (R) dan koefisien determinasi (adjusted $R^{2}$ )

Tabel 5.7 Hasil Uji Korelasi dan Uji Determinasi

\begin{tabular}{ccrrr}
\multicolumn{5}{c}{ Model Summary } \\
\hline Model & $R$ & $R$ Square & Adjusted $R$ Square & Std. Error of the Estimate \\
\hline 1 & $.674^{\mathrm{a}}$ & .454 & .437 & 5.788 \\
\hline
\end{tabular}

a. Predictors: (Constant), APIP, Komitmen, Kesadaran

Sumber: Hasil olah data dengan SPSS

Nilai koefisien korelasi (R) berkisar antara 0 sampai 1, nilai semakin mendekati 1 berarti hubungan yang terjadi semakin kuat, sebaliknya nilai semakin mendekati 0 maka hubungan yang terjadi semakin lemah.

Berdasarkan Tabel 5.7 koefisien korelasi (R) sebesar 0,674 menunjukkan bahwa hubungan antara variabel independen $(\mathrm{X})$ dengan variabel dependen $(\mathrm{Y})$ merupakan hubungan yang kuat. Artinya kesadaran pada peraturan perundang-undangan, komitmen organisasi, dan peran APIP mempunyai hubungan yang kuat terhadap penerapan SAKIP karena mendekati nilai 1.

Jika nilai adjusted $R^{2}$ sama dengan 0, maka variasi variabel independen yang digunakan dalam model tidak menjelaskan sedikitpun variasi variabel dependen. Sebaliknya adjusted $R^{2}$ sama dengan 1, maka variasi variabel independen yang digunakan dalam model menjelaskan $100 \%$ variasi variabel dependen.

Berdasarkan Tabel nilai adjusted $\mathrm{R}^{2}$ adalah 0,437 yang artinya peningkatan penerapan SAKIP sebesar $43,7 \%$ dipengaruhi oleh kesadaran pada peraturan perundang-undangan, komitmen organisasi, dan peran APIP, sedangkan sisanya 56,3\% dipengaruhi oleh faktor-faktor lain di luar penelitian ini.

\subsection{Pembahasan}

\subsubsection{Pengaruh Kesadaran Pada Peraturan Perundang-Undangan Terhadap Penerapan SAKIP}

Setelah melalui hasil analisis dan pengujian hipotesis dapat dikemukakan bahwa kesadaran pada peraturan perundang-undangan tidak berpengaruh signifikan terhadap penerapan SAKIP. Hal ini disebabkan karena terjadi perubahan peraturan perundang-undangan tentang pedoman SAKIP yang belum sepenuhnya bisa dipahami dan diterapkan dengan baik. Hal ini mencerminkan kesadaran pada peraturan perundang-undangan berjalan kurang efektif karena 
kesadaran aparatur terhadap aturan atau hukum masih kurang. Hasil penelitian ini bertolak belakang dengan hasil penelitian Riantiarno dan Azlina (2011), Soleman (2007), Badruzaman dan Chairunnisa (2011), dan Putra (2003) yang menyimpulkan bahwa kesadaaran, kepatuhan atau ketaatan pada peraturan perundang-undangan memiliki pengaruh positif dan signifikan terhadap penerapan sistem akuntabilitas kinerja instansi pemerintah. Namun hasil penelitian ini sejalan dengan penelitian Nasriani dan Chandra (2009), hasil pengujian secara parsial menunjukkan bahwa kesadaran tentang akuntabilitas serta hukum tentang akuntabilitas tidak mempunyai pengaruh yang signifikan terhadap implementasi SAKIP.

Kurangnya kesadaran pada peraturan perundang-undangan khususnya pada peraturan tentang SAKIP dan peraturan tentang penyusunan pelaksanaan pembangunan daerah inilah salah satu yang menyebabkan predikat Pemerintah Provinsi Sulawesi Utara belum dapat mencapai kategori tertinggi berdasarkan hasil evaluasi dari Kemen PAN dan RB.

\subsubsection{Pengaruh Komitmen Organisasi Terhadap Penerapan SAKIP}

Komitmen organisasi berpengaruh signifikan terhadap penerapan SAKIP. Dengan demikian keberadaan komitmen organisasi yang kuat sangat dibutuhkan organisasi agar dapat meningkatkan akuntanbilitas kinerja serta penggunaan yang lebih baik atas informasi kinerja yang dihasilkan. Sistem akuntabilitas kinerja instansi pemerintah akan dapat berjalan dengan baik apabila didukung dengan komitmen yang tinggi dari pemerintah daerah, karena dengan komitmen organisasi yang kuat dimulai dari pimpinan sampai bawahannya maka akan lebih mudah untuk mencapai hasil yang diinginkan untuk menghasilkan kinerja yang lebih baik, dibanding dengan organisasi yang tidak memiliki komitmen. Hasil penelitian ini juga mendukung penelitian yang dilakukan Silvia (2013) bahwa komitmen manajemen berpengaruh signifikan positif terhadap akuntabilitas kinerja instansi pemerintah. Begitu juga dengan penelitian Nusantoro dan Subiyanto (2009), menyimpulkan bahwa komitmen pemerintah daerah secara signifikan mempengaruhi efektivitas penerapan SAKIP.

Pegawai dengan komitmen normatif yang tinggi akan tetap bertahan dalam organisasi karena merasa itu adalah kewajibannya dan harus dilakukan sebagai balasan atas keuntungan yang telah dia terima dari organisasi yang menaunginya. Sebagai bentuk balasan kepada organisasi pegawai yang baik akan memberikan kinerja serta tingkah laku yang baik pula agar bisa diikuti oleh pegawai lain. Sikap ini secara langsung memberikan pengaruh yang positif terhadap penerapan SAKIP pada organisasinya.

\subsubsection{Pengaruh Peran APIP Terhadap Penerapan SAKIP}

Peran APIP berpengaruh signifikan terhadap penerapan SAKIP. Hal ini tidak lepas dari sifat APIP yang semakin independen dalam melaksanakan tugas evaluasi kinerja dan pengawasan lainnya dan APIP memberikan jaminan atas pelaksanaan tugas instansi/organisasi pemerintah. Selain itu juga APIP memberikan arahan perbaikan bila ditemukan hal-hal yang menyimpang pada instansi/organisasi pemerintah. Sehingga peran APIP terhadap penerapan SAKIP pada instansi/organisasi pemerintah pada khususnya dan pemerintah provinsi sulawesi utara pada umumnya berjalan dengan baik sesuai pedoman dan regulasi yang telah dikeluaran. Hasil penelitian Darwanis dan Chairunnisa (2013) menunjukkan bahwa pengawasan kualitas laporan keuangan memiliki korelasi positif dan berpengaruh secara signifikan terhadap akuntabilitas kinerja instansi pemerintah. Sejalan juga dengan penelitian yang dilakukan oleh Astuti (2013), dimana fungsi pemeriksaan intern berpegaruh terhadap kinerja pemerintah daerah, dengan nilai signifikansi sebesar 0,002, karena berada dibawah nilai signifikansi yang dipersyaratkan yaitu 0,05 . 
Peran APIP memberi nilai tambah kepada organisasi sebagai sumber yang objektif melalui saran-saran yang independen atas proses tata kelola, manajemen risiko dan pengendalian internal organisasi.

\section{KESIMPULAN}

Berdasarkan hasil analisis penelitian dan pembahasan maka dapat disimpulkan bahwa:

1. Kesadaran pada peraturan perundang-undangan tidak berpengaruh signifikan terhadap penerapan SAKIP. Hal ini disebabkan karena terjadi perubahan peraturan perundangundangan tentang pedoman SAKIP yang belum sepenuhnya bisa dipahami dan diterapkan dengan baik. Hal ini mencerminkan kesadaran pada peraturan perundang-undangan berjalan kurang efektif karena ketaatan atau kepatuhan terhadap aturan atau hukum masih kurang.

2. Komitmen organisasi berpengaruh signifikan terhadap penerapan SAKIP. SAKIP akan dapat berjalan dengan baik apabila didukung dengan komitmen yang tinggi dari setiap unsur penyelenggara SAKIP itu sendiri, karena dengan komitmen organisasi yang kuat dimulai dari pimpinan sampai bawahannya maka akan lebih mudah untuk mencapai hasil yang diinginkan untuk menghasilkan kinerja yang lebih baik, dibanding dengan organisasi yang tidak memiliki komitmen.

3. Peran APIP berpengaruh signifikan terhadap penerapan SAKIP. Hasil ini tidak lepas dari APIP yang semakin independen dalam melaksanakan tugas evaluasi kinerja dan pengawasan lainnya dan APIP memberikan jaminan atas pelaksanaan tugas instansi/organisasi pemerintah. Selain itu juga APIP. memberikan arahan perbaikan bila ditemukan hal-hal yang menyimpang pada instansi/organisasi pemerintah.

4. Kesadaran pada peraturan perundang-undangan, komitmen organisasi dan peran APIP secara bersama-sama berpengaruh signifikan terhadap penerapan SAKIP.

5. Berdasarkan hasil analisis koefisien determinasi, nilai adjusted R2 dalam penelitian ini adalah 0,437 yang artinya peningkatan penerapan SAKIP sebesar 43,7\% dipengaruhi oleh kesadaran pada peraturan perundang-undangan, komitmen organisasi, dan peran APIP, sedangkan sisanya 56,3\% dipengaruhi oleh faktor-faktor lain di luar penelitian ini.

\section{DAFTAR PUSTAKA}

Asosiasi Auditor Intern Pemerintah. 2013. Standar Audit Intern Pemerintah Indonesia. Jakarta: Komite Standar Audit AAIPI.

Astuti, R. M. 2013. Pengaruh Akuntabilitas, Transparansi dan Fungsi Pemeriksaan Intern Terhadap Kinerja Pemerintah Daerah (Studi Kasus pada Dinas Pendapatan Pengelolaan Keuangan dan Aset Daerah (DPPKAD) Kabupaten Grobogan). Naskah Publikasi. Surakarta: Fakultas Ekonomi dan Bisnis Universitas Muhammadiyah Surakarta.

Ghozali, I. 2006. Aplikasi Analisis Multivariate Dengan Program SPSS. Cetakan Keempat. Semarang: Badan Penerbit Universitas Diponegoro.

Jensen, M. C., and W. H. Meckling. 1976. Theory of the Firm: Managerial Behaviour, Agency Costs and Ownership Structure. Journal of Financial Economics. 3(4): 305-360.

Kelman, H. C. 1958. Compliance, identification, and internalization three processes of atitude change. Conflict Resolution. II(1). Harvard University.

Lembaga Administrasi Negara. 2003. Pedoman Penyusunan Laporan Akuntabilitas Kinerja Instansi Pemerintah. Jakarta 
Lukito, P. K. 2014. Membumikan Transparansi Dan Akuntabilitas Kinerja Sektor Publik: Tantangan Berdemokrasi Kedepan. Jakarta: Grasindo.

Mardiasmo. 2009. Akuntansi Sektor Publik. Yogyakarta: Penerbit Andi.

Meyer, J. P., N. J. Allen., and C. A. Smith. 1993. Commitment to Organisations and Occupations: Extension and test of a Three-Component Conceptualisation. Journal of Applied Psychology, 78(4): 538-551.

Meyer J. P., N. J. Allen.1997. Commitment In The Workplace: Theory Research and Application. Thousand Oaks. California: Sage Publication. Inc.

Muskamal. 2014. Aktualisasi Konsep Birokrasi Dalam Menjawab Tantangan Reformasi Birokrasi Di Indonesia. http://makassar.lan.go.id, diakses tanggal 19 Juli 2016.

Nasriani dan T. Chandra. 2009. Faktor-Faktor Yang Mempengaruhi Implementasi Sistem Akuntabilitas Kinerja Instansi Pemerintah (SAKIP) Di Lingkungan Pemerintah Provinsi Riau. Jurnal Tepak Manajemen Bisnis. 1(3): 107-131.

Norman, F. 2010. Implementasi Sistem Pengukuran Kinerja Satuan Kerja Perangkat Daerah (SKPD) di Kota Bengkulu. Jurnal SNA XIII. Purwokerto.

Nurkhamid, M. 2008. Implementasi Inovasi Sistem Pengukuran Kinerja Instansi Pemerintah. Jurnal Akuntansi Pemerintah. 3(1).

Peraturan Pemerintah Republik Indonesia Nomor 60 Tahun 2008 tentang Sistem Pengendalian Intern Pemerintah.

Peraturan Presiden Republik Indonesia Nomor 29 Tahun 2014 tentang Sistem Akuntabilitas Kinerja Instansi Pemerintah.

Riantiarno, R., dan N. Azlina. 2011. Faktor-Faktor Yang Mempengaruhi Akuntabilitas Kinerja Instansi Pemerintah. Pekbis Jurnal, 3(3): 560-568.

Salman, O., dan A. F. Susanto. 2004. Teori Hukum Mengingat, Mengumpulkan dan Membuka Kembali. Bandung: Rafika Aditama.

Setiyono, B. 2014. Pemerintahan dan Manajemen Sektor Publik: Prinsip-Prinsip Manajemen Pengelolaan Negara Terkini, Yogyakarta: CAPS (Center of Academic Publishing Service).

Silvia. 2013. Pengaruh Keterbatasan Sistem Informasi, Komitmen Manajemen, dan Otoritas Pengambilan Keputusan Terhadap Akuntabilitas Kinerja Instansi Pemerintah (Studi Empiris pada Satuan Kerja Perangkat Daerah di Kota Payakumbuh). Skripsi. Padang: Fakultas Ekonomi Universitas Negeri Padang.

Soekanto, S. 1982. Kesadaran Hukum dan Kepatuhan Hukum. Jakarta: Rajawali Press.

Soleman, R. 2007. Pengaruh Kompetensi, Penerapan Akuntabilitas Keuangan, dan Ketaatan pada Peraturan Perundangan Terhadap Akuntabilitas kinerja Instansi Pemerintah (AKIP). Disertasi. Bandung: Universitas Padjadjaran.

Turner, M., and D. Hulme. 1997. Governance, Administration, and Development: Making The State Work. London: MacMillan Press Ltd.

Weber, M. 1948. From Max Weber: Essays in Sociology. Edited by H. Gerth., and C. W. Mills. London: Routledge and Kegan Paul.

Yuwono, S., et al. 2008. Memahami APBD dan Permasalahannya (Panduan Pengelolaan Keuangan Daerah). Malang: Banyumedia Publishing. 